\title{
Measuring the Critical Factors in Achieving the Effectiveness of Inventory Management in Warehousing
}

\author{
Tarudin N. F., Adlan M. A. A., Abd Latif A., Muhammad Khairi A. T
}

To Link this Article: http://dx.doi.org/10.6007/IJARBSS/v11-i10/10842

DOI:10.6007/IJARBSS/v11-i10/10842

Received: 11 August 2021, Revised: 04 September2021, Accepted: 25 September 2021

Published Online: 09 October 2021

In-Text Citation: (Tarudin et al., 2021)

To Cite this Article: Tarudin, N. F., Adlan, M. A. A., Abd Latif, A., \& Khairi, M. A. T. (2021). Measuring the Critical Factors in Achieving the Effectiveness of Inventory Management in Warehousing. International Journal of Academic Research in Business and Social Sciences, 11(10), 337-348.

\section{Copyright: (c) 2021 The Author(s)}

Published by Human Resource Management Academic Research Society (www.hrmars.com)

This article is published under the Creative Commons Attribution (CC BY 4.0) license. Anyone may reproduce, distribute, translate and create derivative works of this article (for both commercial and non-commercial purposes), subject to full attribution to the original publication and authors. The full terms of this license may be seen

at: http://creativecommons.org/licences/by/4.0/legalcode

$$
\text { Vol. 11, No. 10, 2021, Pg. } 337 \text { - } 348
$$

Full Terms \& Conditions of access and use can be found at http://hrmars.com/index.php/pages/detail/publication-ethics 


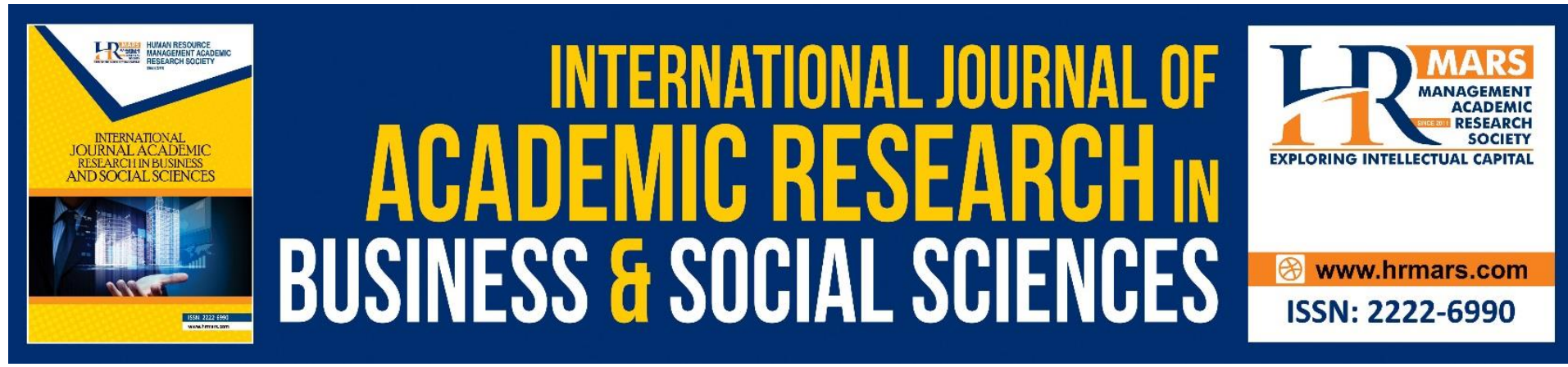

\title{
Measuring the Critical Factors in Achieving the Effectiveness of Inventory Management in Warehousing
}

\author{
${ }^{1}$ Tarudin N. F., ${ }^{2}$ Adlan M. A. A., ${ }^{3}$ Abd Latif A., Muhammad \\ Khairi A. T
}

${ }^{1}$ Malaysia Institute of Transport (MITRANS) and, Faculty of Business and Management, Universiti Teknologi MARA (UiTM), Selangor, Malaysia, ${ }^{2}$ SIME DARBY Rent A Car Sdn Bhd, 3rd Floor, Block B, Lot 13A, Jalan 219, Section 51A, 46100 Petaling Jaya, Selangor, Malaysia,

${ }^{3}$ Faculty of Business and Management, Universiti Teknologi MARA (UiTM), Selangor,

Malaysia, ${ }^{4}$ Malaysia Institute of Transport (MITRANS), Shah Alam, Selangor, Malaysia. Email: ${ }^{1}$ nurfarizan@uitm.edu.my, ${ }^{2}$ m.akmalasyraaf@gmail.com, ${ }^{3}$ azlin469@uitm.edu.my,

4tasnim.khairi1@gmail.com

\begin{abstract}
Inventory management is pivotal in an effective and efficient organization. And it is also vital in the control of materials and goods that have to be held for later use in the case of production or later exchange activities in the case of services. Therefore, this study was conducted to measure the critical factors that helping in achieving the effectiveness of inventory management in the warehouse. Three factors that were involved in this study which are knowledge and skills, documentation and funding. In gathering the data, a set of the questionnaire is distributed to the respective respondent that was related to this area. To analyse the data Statistical Product and Service Solution (SPSS) were used by focusing on correlation and regression analysis. This study is conducted to contribute to the company and to other organizations that find a solution to their inventory problem. Moreover, with this study it helps the company to identify major factors and to solve the inventory issues in the company. Furthermore, the result in this study gives empirical impact on the company in handling inventory. They can refer to this study as a guideline to prepare pre-alert planning to enhance their daily task to achieve the effectiveness of inventory management. By achieving it, they can reduce inventory issues such as missing item, misplaced item and short item.
\end{abstract}

Keywords: Warehouse, Inventory, Documentation

\section{Introduction}

In the world of logistics, many aspects that have to be taken seriously by the player. Modern logistics involves planning, creating and monitoring flows of goods and information. To carry out these jobs, logisticians need to understand and conceive business processes. Although these complex structures may often remain hidden from consumers and logistics 
has long been an indispensable part of daily life. Across industries, it ensures that goods and merchandise are always there when they are needed (DHL logbook, 2011).

Besides that, logistics can be defined as the process of planning, implementing, controlling the efficient, effective flow and storage of goods, services, and related information from point of origin to point of consumption to confirm the customer requirements (Council of Supply Chain Management Professional, 2014). Usually, physical logistics involves the integration of information flow, material handling, warehousing, packaging, production, inventory, and transportation. Warehousing plays a vital role and acts as a place in which goods or merchandise are stored in a large area and sometimes also known as a storehouse.

In logistics, inventory is one of its activities. It is also called stock by logisticians and act as central to logistics management. According to Saxena (2009), inventory can be defined as an idle resource of any kind that has potential economic value and is considered as locked up capital. The company needs to manage well their inventory in the warehouse. Most of the logistics company's objectives are reducing costs and increasing revenue (Lemke, 2015). Therefore, most of the logistician needs to control their inventory accordingly. Low inventories will result in payment of fewer interest charges on capital locked up and also release the much wanted and same capital for alternative uses. For this study, the researchers have a focus on the factor that will contribute toward achieving the effectiveness of inventory management. The empirical study has been conducted in one logistics company and as it was involved with certain private and confidential information, the researchers have named this company as XYZ Company.

In managing their inventory, XYZ Company was used the Supplier Inventory Management System (SIMS) and this system was consists of stock inquiry, basically using to locate or find the item or goods at the rack location. Other functions are stock adjustment and stock transfer. This system is used to move the item at the rework location from Value Added Services (VAS) to the rack location in the warehouse. Moreover, the department of inventory in this company needs to do optimization and cycle count. This process is repeated on a daily basis in order to fully utilized space at the rack location in the warehouse.

\section{Issues and Problem Statement}

Every company are seeking a way to improve its own business efficiencies and cutting cost. For logistics companies, inventory management is one of the areas that most of the management is focus on. It functions involves multiple locations, customers, process and also depends upon physical operation. Therefore, many computerised system setups were used in handling and managed the inventory.

However, several issues arose regarding inventory in logistics industries. One of those is inaccurate issues. Inaccuracy is one of the biggest problems that companies are facing at the warehouse. Inaccuracy takes in inaccurate quantity and inaccurate storage location. According to Agrawal and Smith (2009), inventory inaccuracy occurs when the system inventory according to the information system (IS) is available does not match the physical inventory. For example, when searching for inventory the location for an item cannot be located or cannot be found. For another example, when searching for the item the quantity of the item is not matched with the system and it was happened because of the inaccurate count of the inventories. In the other words, an inventory stock is inaccurate when the record stock is not the same as the physical stock and is also recorded in the system (Shteren \& Avrahami, 2017). 
Another issue related to inventory is the lack of training of staff to handle inventories in the warehouse. Issues that involve inventory such as accuracy can get traced back to human error. Most of the companies are less to give training to their employee. Therefore, an unskilled employee for example under qualified forklift driver is more likely to damaged items during inventory put away. According to Peck, Sniffin, Isman, and Austin (2014), providing training can improve effectiveness and efficiencies in operating a business and improved knowledge of staff to explain the nature of change and the impact it has on the services they rely on. Thus, proper training can increase a warehouse's efficiency and productivity and decreases inventory management issues.

Last but not least, the normal issue faced by companies who are running logistics is the damage of goods or items (Chan, 2020). Inventory is being handled multiple times in a warehouse. Every time when the goods are moving or being touched it leads becomes susceptible to damage. Therefore, many companies gain losses due to the damage. According to Ketzenberg and Ferguson (2007), firms in the US gain \$200 billion a year but, subjecting firms to losses of up to $15 \%$ due to damage and spoilage. Therefore, many companies selling those damaged items at a substantial discount to the public to recoup some of their finances. In addition, some of the company needs to repay the damaged item to the customer.

An inventory is important to the business to determine its profit and success of the business. But the normal issue involves with inventory management caused an effect that leads to inefficient inventory management. One of the effects is losses. If the staff do not know where the things are in the warehouse and indeed whether the staff do not have any at all, then the pick, pack, and ship processes is significantly more inefficient.

According to Smaros, Lehtonan, Appleqvist, and Holmstrom (2003), inventory should be properly managed in order to deliver and to give an effective flow of operation. Therefore, when the company is properly managed their inventory it can avoid losses and bottlenecks of operation. This is mean if too many orders come in for outgoing shipment by having effective control of inventory and handled in an efficient manner it can reduce bottleneck and losses of goods. Thus, it can increase productivity hence it can increase revenue to the company.

Moreover, the effects of inefficient inventory management are leads to higher cost investment in managing inventory. According to Imeokparia (2013), hidden costs, labour costs and other costs associated with inventory mismanagement and poor performance thus, need to assign accountability for inventory management. Every dollar invested in inventory represents a dollar that is unavailable for other purposes in the enterprise (MacKinnon, 2005). Inventory constitutes the most significant part of the current asset in the XYZ Company. It is a considerable sum of and organizations fund is being committed to them because of its largeness of inventories maintained by the company. In order to avoid the superfluous costs and ensure an elevated level of customer services, thus becomes absolutely imperative to manage inventories effectively.

\section{Conceptual Framework}

Based on the preliminary study with six staff, the result shows in figure 1. Fourteen percent comes from the problem that might have been attributed to poor funding by the management. Moreover, twenty-nine percent because of poor documentation that possibility of inaccurate recording or poor centring of some data information. For example, the stock inquiry information provided by the system and the actual physical stock is not tally. Last but not least, most of the staff stated that fifty-seven percent of the problem comes from 
the knowledge and skill possessed by the staff whose capability and qualification needs to be reviewed on how they manage their inventory.

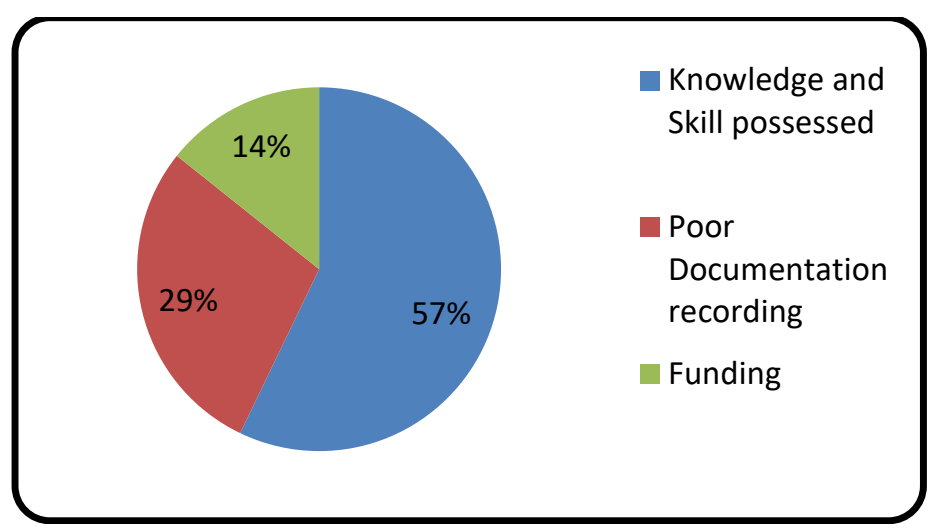

Figure 1. Issues and Problem

At last but not least, the purpose of this study is to identify the factor that affects inventory management. Therefore, appropriate solutions and recommendations can be provided to the company in order to manage effectively inventory. Hence the conceptual framework for this study is based on the previous researches that have been done by other researchers together with the preliminary results that was gathered. Therefore, in this study, the dependent and independent variables are shown in figure 2.

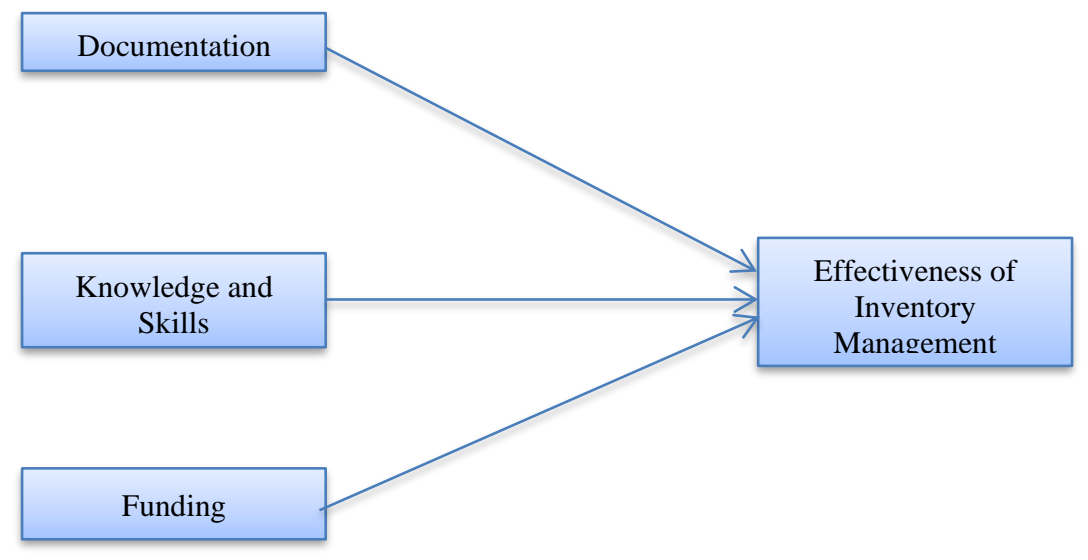

Figure 2. Conceptual Framework

Documentation is important to ensure the effectiveness of inventory management (Chan, 2017). Therefore, it is important to have a present of good documentation for example store record card with valuable information that can record the details of goods. In this documentation, the researcher is focusing on the information that is being used in handling inventory.

The level of knowledge and skills possessed by the staff is important because the level of education possessed by staff affect the effectiveness of handling goods or items in the warehouse (APICS, 2011). Moreover, such training should be provided by the manager to ensure appropriate training can be done to increase the knowledge and skills possessed by staff that can improve inventory management. In this knowledge and skills, the researcher is 
focusing on what is the knowledge and skills possessed by the employee in handling inventory.

Allocation of funding in inventory management is imperative to ensure the operation of inventory (Ng'ang'a, 2013). Moreover, funding is important in order to implement a new system of inventory to increase the inventory management and maintenance of material handling equipment (MHE) (Andiyappillai, 2019). In this the researcher is focusing on the funding that should be allocated to the inventory department.

Those three factors above will influence the dependent variable which is the effectiveness of inventory management. In which this can be whether the factors are giving a negative or a positive way towards the organizational performance.

\section{Methodology}

The method used for this study is simple random sampling which is a questionnaire that will be distributed to random workers in the XYZ Company. This is an appropriate method for this study because it was involved with the least biased and offers the most generalizability. The target respondent for this study is staff in all levels of departments such as managers, supervisors, leaders in each department, permanent staff and also contract staff in XYZ Company. The researchers choose this company and the branch because it contributes to higher profit and has a bronze lean award from another branch in Malaysia. Based on the Human Resource Department for the population of the XYZ Company has 150 totals workers. For the purpose of this study, the sample size will consist of 93 respondents from 150 of the total's population. After the survey has been made and the data has been gathered, statistical equipment is known as Statistical Product and Service Solution (SPSS) version 20 has been used to compute data from questionnaires to get the exact and final results.

Once the instrument was ready, pilot testing was done to determine the appropriateness of the questionnaire before actual data collection will run. This pilot testing was analysed by using reliability testing and looking at Cronbach Alpha results (Tarudin et. al., 2018). To interpret the reliability of the variables and the questions asked, the Cronbach alpha coefficient is considered. The closer the coefficient to the value of one (1), the higher the internal consistency reliability is. The interpretation of the Cronbach alpha coefficient is shown in the table below

Table 1. The interpretation of Cronbach's alpha coefficient

\begin{tabular}{|c|c|c|}
\hline $\begin{array}{l}\text { Cronbach's } \\
\text { Range }\end{array}$ & Alpha Coefficient & Strength of Association \\
\hline$<0.5$ & & Poor \\
\hline 0.6 to 0.79 & & Acceptable \\
\hline$>0.8$ & & Good \\
\hline
\end{tabular}


Table 2. shows that the Cronbach's alpha coefficient obtained in this study is 0.882 . Based on Table 2, shows that the set of the questions asked has a good strength of association and that the questionnaire is reliable enough to be distributed for the data collection process.

Table 2. Cronbach's Alpha Reliability Statistics Table

\begin{tabular}{ll}
\hline Cronbach's Alpha & N of Items \\
\hline 0.882 & 20 \\
\hline
\end{tabular}

\section{Findings and Discussion}

In measuring the critical factors for achieving the effectiveness of inventory management in warehouses, the researchers looked at two types of analysis which are Pearson Correlation Analysis and Regression analysis. Guildford's Rule of Thumbs was being the guideline in interpreting and assessing the correlation's strength between both dependent and independent variables Pearson Correlation Analysis (Adlan et. al., 2019).

Table 3. Guildford's Rules of Thumbs

\begin{tabular}{|ll|}
\hline $0.00-0.29$ & Interpretation \\
\hline $0.30-0.49$ & Slightly or negligible relationship \\
\hline $0.50-0.69$ & Low correlation or relationship \\
\hline $0.70-0.89$ & Moderate or marked relationship \\
\hline $0.90-1.00$ & High correlation or relationship \\
\hline
\end{tabular}

In the first place of analysis, the researchers looked at the correlation between the variable to assess their relationship. By referring to Table 4., it was shown that knowledge and skills have a high relationship with dependent since the value of " $p$ " is 0.725 , while documentation and funding have a moderate relationship with the value of " $p$ " is 0.658 . Based on this result, it was shown that these factors have influences on the dependent variable and the management of the company can use these factors as their measurement. The detailed result has been shown in the table below: 
Table 4. Pearson Correlation

\begin{tabular}{|c|c|c|c|c|c|}
\hline & & & & & Effectivenes \\
\hline & & $\begin{array}{l}\text { Knowledg } \\
\text { e \& Skills }\end{array}$ & $\begin{array}{l}\text { Docume } \\
\text { ntation }\end{array}$ & $\begin{array}{l}\text { Fundin } \\
\mathrm{g}\end{array}$ & $\begin{array}{l}\text { S of } \\
\text { Inventory } \\
\text { Mgt }\end{array}$ \\
\hline & Pearson & & & & \\
\hline & Correlatio & 1 & $.570^{* *}$ & $.514^{* *}$ & $.725^{* *}$ \\
\hline Knowledg & $n$ & & & & \\
\hline e \& Skills & $\begin{array}{l}\text { Sig. } \\
\text { tailed) }\end{array}$ & & .000 & .000 & .000 \\
\hline & $\mathrm{N}$ & 74 & 74 & 74 & 74 \\
\hline & Pearson & & & & \\
\hline & Correlatio & $.570^{* *}$ & 1 & $.559^{* *}$ & $.600^{* *}$ \\
\hline Document & $\mathrm{n}$ & & & & \\
\hline ation & $\begin{array}{l}\text { Sig. } \\
\text { tailed) }\end{array}$ & .000 & & .000 & .000 \\
\hline & $\mathrm{N}$ & 74 & 74 & 74 & 74 \\
\hline & Pearson & & & & \\
\hline & $\begin{array}{l}\text { Correlatio } \\
n\end{array}$ & $.514^{* *}$ & $.559^{* *}$ & 1 & $.566^{* *}$ \\
\hline Funding & $\begin{array}{l}\text { Sig. } \\
\text { tailed) }\end{array}$ & .000 & .000 & & .000 \\
\hline & $\mathrm{N}$ & 74 & 74 & 74 & 74 \\
\hline & Pearson & & & & \\
\hline Effectiven & Correlatio & $.725^{* *}$ & $.600^{* *}$ & $.566^{* *}$ & 1 \\
\hline ess of & $\mathrm{n}$ & & & & \\
\hline $\begin{array}{l}\text { Inventory } \\
\text { Mgt }\end{array}$ & $\begin{array}{l}\text { Sig. } \\
\text { tailed) }\end{array}$ & .000 & .000 & .000 & \\
\hline & $\mathrm{N}$ & 74 & 74 & 74 & 74 \\
\hline * Comu & ion is signifi & ant at tho & 1 level & ailed). & \\
\hline
\end{tabular}

The fitness of the conceptual framework of this study was interpreted in the model summary that was gathered under the regression analysis section. This model summary (Table 5.) were given certain information about the goodness of a model fit. The statistic value that showed under the $\mathrm{R}$ square was given an indication of how good the independent variable is in predicting the value of a dependent variable. It describes the amount of variation independent variable values explained by the regression line. The larger the value, the better the regression line describes the data. In this study, the $R$ square value is .600 . It means 60 percent of the variance can be explained by the variation in the independent variables which are knowledge and skills, documentation and funding. 
Table 5. Regression Coefficient

\begin{tabular}{|c|c|c|c|c|c|c|}
\hline \multirow{2}{*}{\multicolumn{2}{|c|}{ Model }} & \multicolumn{2}{|c|}{$\begin{array}{l}\text { Unstandardized } \\
\text { Coefficients }\end{array}$} & \multirow{2}{*}{$\begin{array}{l}\text { Standardized } \\
\text { Coefficients } \\
\text { Beta }\end{array}$} & \multirow[t]{2}{*}{$\mathbf{t}$} & \multirow[t]{2}{*}{ Sig. } \\
\hline & & B & $\begin{array}{l}\text { Std. } \\
\text { Error }\end{array}$ & & & \\
\hline \multirow{4}{*}{1} & (Constant) & .379 & .509 & & .745 & .459 \\
\hline & $\begin{array}{l}\text { Knowledge and } \\
\text { Skills }\end{array}$ & .509 & .095 & .512 & 5.332 & .000 \\
\hline & Documentation & .222 & .110 & .201 & 2.021 & .047 \\
\hline & Funding & .230 & .115 & .191 & 2.008 & .049 \\
\hline
\end{tabular}

a. Dependent Variable: Effectiveness of Inventory Management

There is an interesting value that was gathered under regression analysis data. As shown in Table 6, the researchers were interested in comparing the contribution of each independent variable therefore beta value in column standardized coefficients. The largest beta coefficient is .512 which is for knowledge and skills and followed by documentation which is. 201 . This means that these two variables in the model make the strongest unique contribution to explaining the dependent variable when the variance explained by all other variables in the model is controlled for. The Beta value for funding was slightly lower .191, indicating that it made less of a unique contribution. Moreover, there is a variable is making a statistically significant unique contribution to the equation.

In order to check the value for each variable, the value in the column marked sig is used. According to Pallant (2010), if the sig value is less than .05, the variable is making a significant unique contribution to the prediction of the dependent variable. If greater than .05 , it can be concluded that the variable is not making a unique contribution to the prediction of the model. In this study, knowledge and skills, documentation and funding made a unique, and statistically significant, with a value less than .05 , those contribute to the prediction of effective inventory management. With the result, it can be concluded that the knowledge and skills, documentation and funding are the critical factors that can help in achieving the effectiveness of inventory management, especially in the logistics industry.

\section{Conclusion and Recommendations}

This study contributes to the effectiveness of inventory management. Furthermore, it also provides an insight into the level of effectiveness of inventory management which may be essential for Menlo in order to take necessary action to try their best in meeting the effectiveness. In the light of the findings, several recommendations have been agreed by the employee that may be implemented in future for the company. 


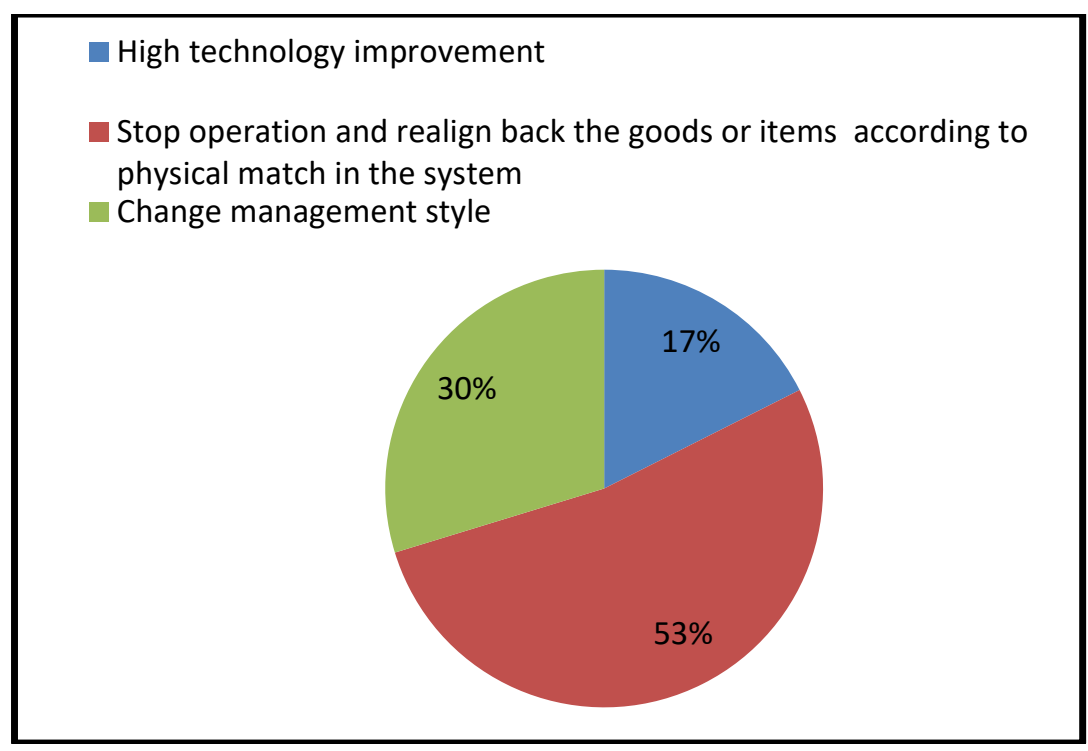

Figure 3. Suggestion and Recommendation

As shown in table 5 above 53 percent answered stop operation and realign back the goods or items according to physical match in the system. Moreover, 30 percent answered change management style. Last and not least, 17 percent choose high technology improvement. Based on the result, it shows that most of them choose to stop the operation and realign back the goods or items according to physical match in the system. In order to do so, the XYZ Company needs to stop their daily operation for about 1 week to realign back. This is to ensure that stock take or cycle count can be done smoothly. Therefore, with that, they can match the location accuracy and quantity accuracy in excellent condition. On top of that, there will be no issue of shortage when the goods move to the outbound process. For best practice is to stop all operations and does stock take or cycle count. This is because inventory is one of the important parts of warehousing. Without, optimizing and daily cycle count it will give a big impact on order processes that involve inventory. For example, order process and order picking need a location number to locate where are the goods. Therefore, inventory department needs to do optimizing which clear all empty location and updated in the system. For the XYZ Company in order to realign back the location and quantity accuracy, Menlo needs to do a stock take and stop the operations. Therefore, if the goods are in large quantity and have a variety of models, they need to segregate the goods and at least to complete the process it needs 1 week or 2 weeks. This is because, after the stock take or cycle count process, they need to do reconciliation. This is the next process to match the system location and quantity accuracy with physical location and quantity accuracy. Next, they need to find the variance of each model. If it has a large variance, they need to recount back the model. After that, they need to match physical location and quantity with the system.

In a conclusion, the researchers have identified the critical factors of the effectiveness of inventory management. Therefore, the critical factors are knowledge and skills, documentation and funding. Several recommendations have been raised and that is stopping the operation and realigns back the goods or items physical match with the system. Therefore, this study can serve as a guideline to the company to achieve the effectiveness of inventory management. Moreover, it is recommended for other researchers to continue this study in order to cover the other factor for achieving this effectiveness for inventory management. Lastly, for the company, it needs to stop operation and realign back the goods 
or items physical match with the system in order to achieve the effectiveness of inventory management.

\section{References}

Adlan, M. A. A., Tarudin, N. F., Kordi, N. E., \& Aziz, T. N. A. (2019). The Accuracy of Datria System in Improving Order Picking Process. International Journal of Recent Technology and Engineering (IJRTE). ISSN: 2277-3878, Volume-8 Issue-4, November 2019.

Agrawal, N., \& Smith, S. A. (2009). Retail Supply Chain Management: Quantitative Models and Empirical Studies. New York: Springer Science+Business Media, LLC.

Andiyappillai, N. (2019). Implementing Warehouse Management Systems (WMS) in Logistics: A Case Study. International Journal of Logistics Systems and Management 2(1):12-23. DOI:10.5281/zenodo. 2576011

APICS. (2011). Retrieved 20 July, 2021, from DISTRIBUTION AND LOGISTICS MANAGERS: Competency Model: http://www.apics.org/docs/careers-development/distribution-and logistics-managers-competency-model.pdf?sfvrsn=0

Chan, M. (2020). 7 Types of Inventory Risk and Their Impact On Your Business. Unleashed an acess company.

Chan, S. W. (2017). Factors Influencing the Effectiveness of Inventory Management in Manufacturing SMEs. IOP Conference Series Materials Science and Engineering 226. DOI:10.1088/1757-899X/226/1/012024. Conference: International Research and Innovation Summit 2017.

Council of Supply Chain Management Professional. (2014). Retrieved 20 July, 2021, from Supply Chain Management Terms and Glossary:

http://cscmp.org/sites/default/files/user_uploads/resources/downloads/glossary2013.pdf

DHL Logbook. (2011). Retrieved 20 July, 2021, from Discover Logistics. DHL - EN: http://www.dhl-discoverlogistics.com/cms/flash/\#/en/

Imeokparia, L. (2013). Inventory Management System and Performance of Food and Beverages Companies in Nigeria . Journal of Mathematics, Volume 6, Issue 1, pp 24-30.

Ketzenberg, M. E., \& Ferguson, M. (2007). Managing Slow Moving Perishables in the Grocery Industry. Retrieved 20 July, 2021, from

smartech.gatech.edu:https://smartech.gatech.edu/bitstream/handle/1853/13469/Man

aging\%20Slow\%20Moving\%20Perishables\%20in\%20the\%20Grocery\%20Industry.pdf;jses sionid=F9C38309CF0AE72D99FC500B738AE12F. smart2? sequence $=1$

Lemke S. W. (2015). Inventory Optimization in Manufacturing Organizations. Walden University ScholarWorks.

MacKinnon, D. J. (2005). Knowledge as Inventory: Near-Optimizing Knowledge and Power Flows in Edge Organizations (Phase One). California: Stanford University, Terman Engineering Center.

$\mathrm{Ng}^{\prime}$ ang'a, K. J. (2013). An Assessment of the Factors Influencing Effectiveness of Inventory Control. International Journal of Business and Commerce, Vol. 3, No.1, pp. 33-53.

Peck, P., Sniffin, T., Isman, M., \& Austin, M. (2014). Effectiveness and Efficiency: Seven Leadership Practices for Meeting the Mission Challenge in an Era of Declining Budgets. Retrieved 20 July, 2021, from Booz Allen Hamilton:

http://www.slideshare.net/BoozAllen/effectiveness-and-efficiency

Saxena, R. S. (2009). Inventory Management: Controlling in a Fluctuating Demand Environment. New Delhi: Global India Publication Pvt Ltd.. 
Shteren, H., \& Avrahami, A. (2017). The Value of Inventory Accuracy in Supply Chain Management - Case Study of the Yedioth Communication Press. Journal of Theoretical and Applied Electronic Commerce Research ISSN 0718-1876 Electronic Version. VOL 12 / ISSUE 2 / MAY 2017 / 71-86. (C) 2017 Universidad de Talca - Chile.

Småros, J., Lehtonen, J.-M., Appelqvist, P., \& Holmström, J. (2003). The impact of increasing demand visibility on production and inventory control efficiency. International Journal of Physical Distribution \& Logistics Management, Vol. 33 Iss: 4, pp.336 - 354.

Tarudin, N. F., Kordi, N. E., Aziz, T. N. A., \& Adlan, M. A. A. (2018). The inclination of oil and gas supply base personnel towards safety compliance. AIP Conference Proceedings 2020, 020052 (2018); https://doi.org/10.1063/1.5062678. 